\title{
A TRIONYCHIDAE (REPTILIA: TESTUDINES, CRYPTODIRA) FROM THE PLIOCENE OF COSTA RICA, SOUTHERN CENTRAL AMERICA
}

\author{
César Laurito M. ${ }^{1}$, Ana Lucía Valerio Z. ${ }^{2}$, Luis Diego Gómez P. ${ }^{3}$, \\ Jim I. Mead ${ }^{4}$, Eduardo Antonio Pérez G. ${ }^{5}$ \& Luis Gerardo Pérez R. ${ }^{3}$ \\ ${ }^{1}$ Instituto Nacional de Aprendizaje, Núcleo de Turismo, \\ Apdo. 203-2200, Coronado, Costa Rica; E-mail: cesarlaurito@ice.co.cr \\ ${ }^{2}$ Departamento de Historia Natural, Museo Nacional de Costa Rica \\ Apdo.749-1000, San José, Costa Rica; E-mail: alvalerio@ costarricense.cr \\ ${ }^{3}$ Organización para Estudios Tropicales, Universidad de Costa Rica \\ Apdo. 676-2050, San Pedro, Costa Rica; E-mail: ldgomez@sloth.ots.ac.cr \\ ${ }^{4}$ Laboratory of Quaternary Paleontology, Quaternary Sciences Program and Dep. of Geology, \\ Northern Arizona University, Flagstaff, Arizona, USA 86011 \\ E-mail: James.Mead@nau.edu \\ ${ }^{5}$ Dirección de Geología y Minas, Ministerio del Ambiente y Energía \\ Apdo. 62-1009, San José, Costa Rica; E-mail: eperez@ costarricense.cr
}

(Recibido 25/5/05; Aceptado 11/7/05)

\begin{abstract}
Fossil remains of soft-shelled turtles, Trionychidae, are recorded from the Pliocene fluvial sediments of Costa Rica. This is the first record of the trionychids from the Neotropical lands of Central America. These fossils revealed new faunal elements involved in the American Biotic Interchange, and permit a better knowledge of the evolution and composition of our paleoherpetofauna.

Keywords: Reptilia, Testudines, Trionychoidea, Apalone, lower Pliocene, Costa Rica.

RESUMEN: Restos fósiles de tortugas de caparazón blando han sido recuperados de sedimentos fluviales del Plioceno de Costa Rica. Esta es la primera vez, fuera del hallazgo venezolano que un trionychido es descrito para la Región Neotropical y para América Central. Su registro aporta nuevos elementos a la fauna involucrada en el Intercambio Biótico entre las Américas y permite una mejor comprensión de la composición y evolución de nuestra herpetofauna.

Palabras clave: Reptilia, Testudines, Trionychoidea, Apalone, Plioceno Inferior, Costa Rica.
\end{abstract}

\section{INTRODUCTION}

Soft-shelled turtles of the family Trionychidae today live in rivers and freshwater swamps of Asia, the Indo-Australian archipelago, Intertropical Africa, and North
America. They are characterized in the Western Hemisphere by a distribution in predominantly temperate habitats of North America, although they do range into the subtropical region of northeastern Mexico; they do not currently live in Central or South America. 
Fossil trionychids have been found in Europe and elsewhere in that hemisphere (see discussion in Webb, 1990). Tertiary sediments in North America frequently contain trionychids, which have been reported in the genus Trionyx, but now placed in the genus Apalone (see Meylan, 1987). An unusual find of a trionychid was described from sediments of Huayquerian age (Pliocene) from Venezuela, South America (Wood \& Patterson, 1973). The appearance of a trionychid in South America is not understood and assumed to have occurred via waif dispersal which did not result in colonization (Estes \& Báez, 1985). An additional possibility is that trionychids entered South America over land via Central America. Reports of fossil turtles from Central America are rare; any record is of importance. Acuña and Laurito (1996) record a late Neogene fossil Rhinoclemmys (Emydidae) from Costa Rica. Here, we report on the first record of the trionychid, Apalone, from the Pliocene of Costa Rica.

The specimens collected by Luis Gerardo Pérez Rivera and presented here come from the locality of Limoncito (8 $51^{\prime}$ '23.8' $\mathrm{N}$ and 8304'19.9" W), located 14 km west of San Vito, Canton of Coto Brus in the province of Puntarenas (Fig. 1).

\section{PALEONTOLOGY}

Class Reptilia

Order TESTUDINES

Suborder CRYPTODIRA

Superfamily TRIONYCHOIDEA

\section{Family TRIONYCHIDAE}

Upper Jurassic - Lower Cretaceous - Recent

The Trionychidae family is typified by primarily carnivorous, freshwater turtles. They are characterized by a shell lacking epidermal scutes, replaced instead by a soft cover of leathery skin. The shell is low, rounded, and typically lacks the peripheral bones and marginal scutes (Carrol, 1988).
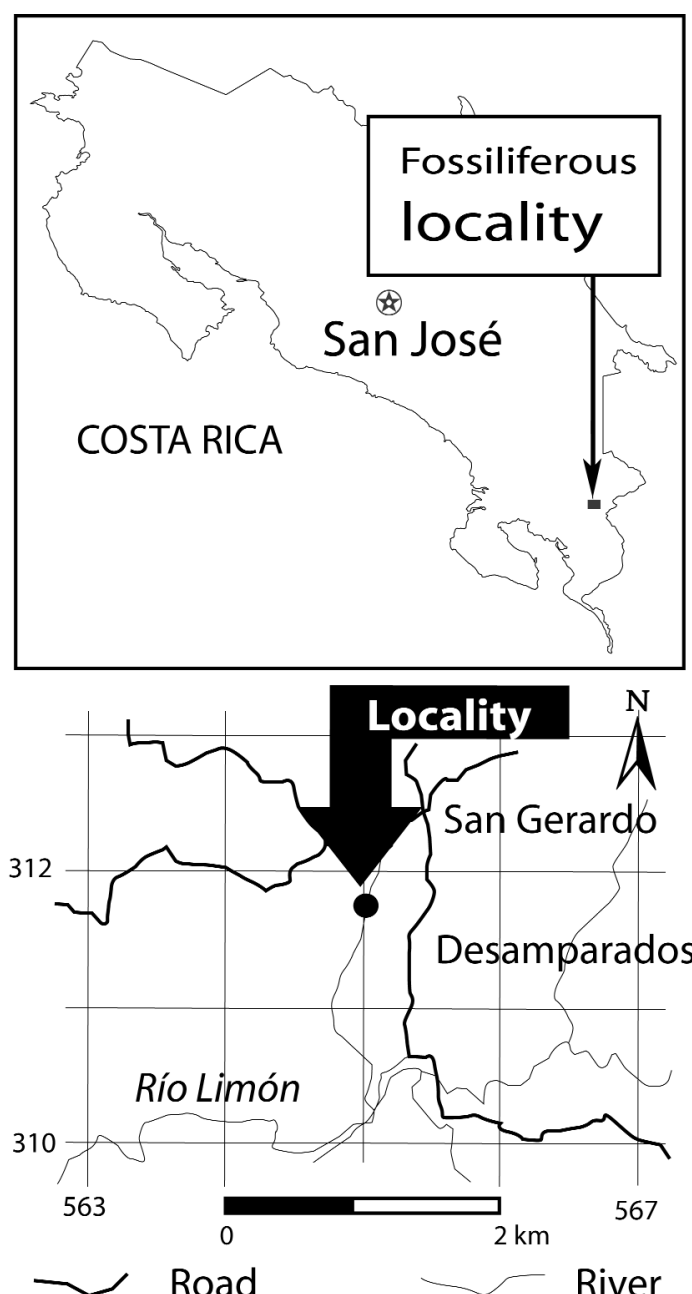

Fig. 1: Map of the locality of Limoncito, canton of Coto Brus Puntarenas, Costa Rica.

\section{Genus Apalone}

Late Miocene - Recent

The trionychids of North America historically have been referred to the genus Trionyx and to another less common genus, Amyda, but are now considered to belong to the single taxon Apalone (Hulbert, 2001). Meylan (1987) revised this group and determined that the generic name Apalone is the most appropriate for the North American trionychids.

Apalone is a freshwater turtle with a soft shell, lacking the epidermal, keratinous scutes 
and peripheral skeletal elements of the carapace, which is covered instead with a leather-type skin. The plastron is highly modified and reduced. The osteology of this genus has been discussed in detail by Sheil (2003).

The external surface of the shell bones is greatly dimpled with round to oval depressions which form a unique pattern, a distinctive character that permits generic identification, of even small fragments of the carapace or plastron (Hulbert, 2001).

\section{Apalone sp. indet.}

\section{Material}

Five shell specimens appear to correspond to fragments of the hyoplastron or hypoplastron and fragments of the costal elements (figure 2 a-e). All specimens are housed at the Geology Section of the Natural History Department of the Museo Nacional de Costa Rica, with specimen numbers CFM-1163-1166 and 1193.

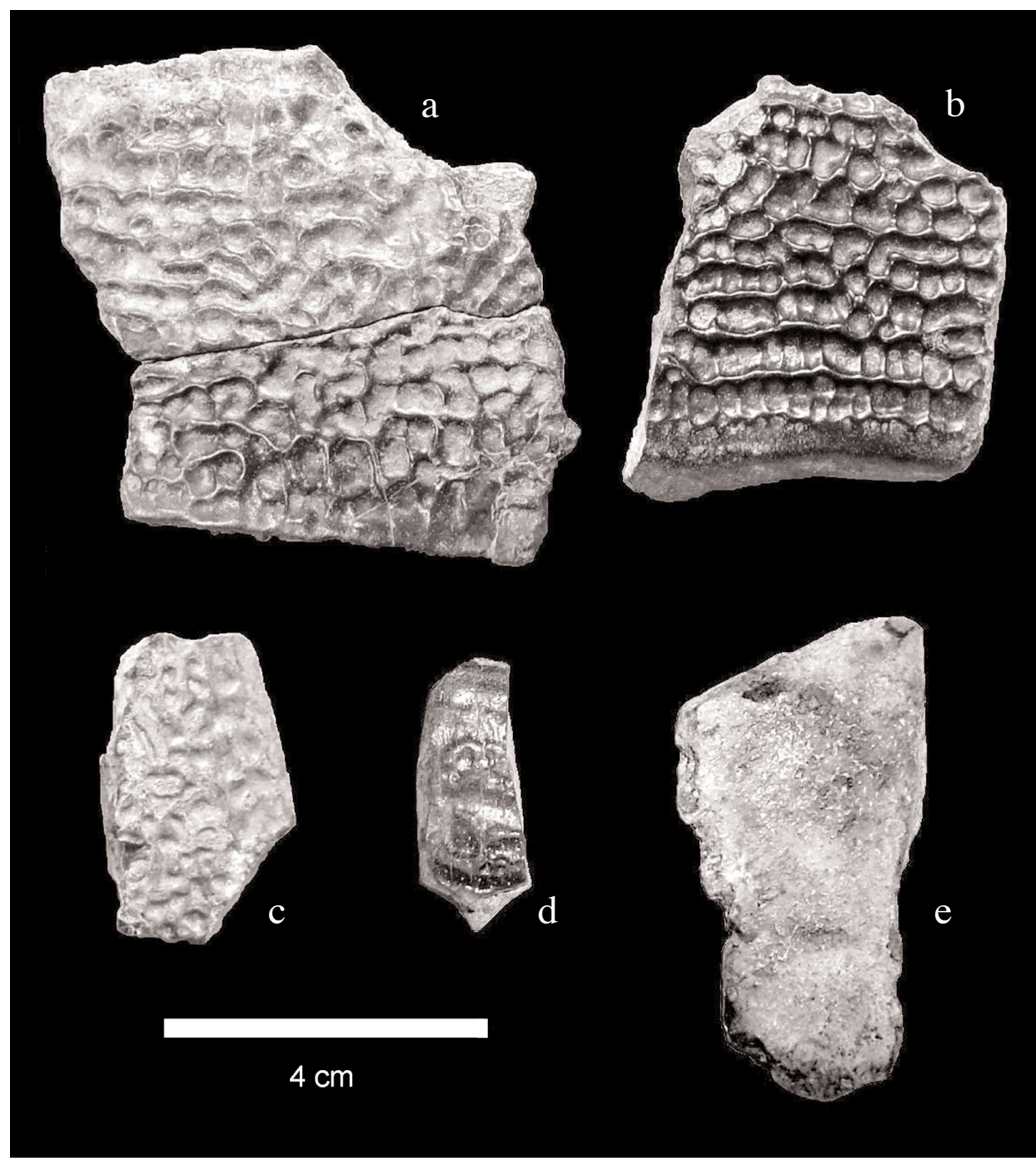

Fig. 2: Scutes of Apalone sp.: a) CFM-1163; b) CFM-1164, c) CFM-1165, d) CFM-1166 and e) CFM-1193. All of uncertain position, corresponding to costal elements or fragments from the hyo-hypoplastron. 


\section{Description}

The recovered fragments are small in size (59 $\mathrm{mm} \times 55 \mathrm{~mm}$ or $37 \mathrm{~mm} \times 25 \mathrm{~mm}$ ) and are characterized by having the unique, highly dimpled surface pattern and are identifiable to the genus Apalone. Without larger specimens or more of an articulated specimen, the species cannot be determined.

\section{DISCUSSION}

The distinctive dimpled pattern of sculpture of the shell fragments permits the identification to Apalone. The specimens phenotypically resemble the living species $A$. ferox:; although, the fossils seem to have a much more conspicuous sculpture than those of the living taxon. We question whether the Costa Rican specimens represent the living form, and suggest that additional and articulated specimens be used at a later date to determine what species lived in Central America in the Pliocene.

\section{Discussion about the probable origin and the Paleobigeography of the Costa Rican Apalone}

When Wood \& Patterson (1973) described the finding of the fossil trionychid from the Urumaco Formation of Venezuela, they assigned a Huayquerian mammal age, equivalent to the Middle Pliocene. Refinement of the age by Marshall (1985; see Estes \& Báez, 1985) sets an Upper Miocene age for the Huayquerian (6 to 9 Ma). Most recent estimate is by Flynn and Swisher of 6.8-9.0 MA. Sánchez-Villagra et al. (2004) described remains of an undetermined genus within the Trionychoidea from the Lower Miocene of the Cerro La Cruz, Castillo Formation, Venezuela. Meylan in SánchezVillagra et al. (2004) presents an unpublished record of Apalone sp. from the Pleistocene of Guatemala.

Wood \& Patterson (1973) assumed that the South American trionychids arrived during the early Miocene through the Central American island arc. However, this possibility is not likely because during the middle and late Miocene the Straits of Bolivar (Central American Isthmus) were wide and constituted a marine barrier that would have limited most terrestrial vertebrates (Whitemore \& Stewart, 1965), possibly including the trionychids. It is not until approximately $6 \mathrm{Ma}$. that the deep marine passage of the Straits of Bolivar started to close (Duque-Caro, 1990 a and b). The isthmus was closing throughout the latest Miocene and most of the Pliocene, with the only possible migration via waif dispersal from the emerging island land masses. A complete land corridor was not viable until at least 3.5 Ma (DuqueCaro, 1990 a).

The overview of the growing fossil record indicates that trionychids and other turtles were a component of the latest Miocene and Pliocene faunas as the isthmus formed. The Apalone sp. specimens reported here are clearly of lower Pliocene age (representative of the Blancan land mammal age). These fossils are from Curré Formation, where remains of Rhynchotherium blicki have been recovered and confirm this age assignment (Laurito \& Valerio, in press). The trionychid remains suggest a dispersal route through low elevation wetlands of the emerging isthmus. The fossil records of trionychids recovered from Miocene deposits in Venezuela are intriguing and suggest an introduction into South America via waif dispersal. Clearly more evidence from Miocene and Pliocene deposits is needed to fully understand the early dispersal of this aquatic turtle.

\section{Paleoecology}

Apalone fossils were recovered from clastic sediments of variable grain size, including middle and coarse sands and fine conglomerates. However, based on the new paleontological finds (such as numerous fossils of large crocodiles, fishes, and mammals) found associated with the Apalone, the fauna permits a reconstruction of an extensive wetland along with associated river mouths near to the coast. 


\section{CONCLUSIONS}

The first fossil record for Central America of the trionychid Apalone is described from the Limoncito locality in Costa Rica. This fossil data not only enriches the Costa Rican paleovertebrate record, but also widely enhances the knowledge and the evolution of the herpertofauna, particularly the turtle record of Central America. The new data suggest that sediments of an ancient fan delta unit of the Curre Formation were deposited in low wetlands environments. It is not possible to unequivocally establish the path of dispersion for this North American genus. The Costa Rican fossils presented here are located in a geographical intermediate point between the known distribution of the living $A$. ferox and the Miocene data set from Venezuela. These important finds illustrate the need for further work on the latest Miocene, Pliocene, and earliest Pleistocene fossil deposits in this North American and South American corridor.

\section{ACKNOWLEDGEMENTS}

This research was made possible by the cooperation of the Organization for Tropical Studies, ESCOGroup, San Jose, and private donations.

\section{BIBLIOGRAPHY}

ACUÑA, R.A. \& LAURITO, C.A., 1996: Nueva especie de Rhinoclemmys Fitzinger, 1836 (Chelonii, Cryptodira) del Cenozoico Tardío de Costa Rica. - Ameghiniana (Rev. Asoc. Paleontol. Argent.), 33(3): 271-278.

CARROL, R.L, 1988: Vertebrate paleontology and evolution. - 698 págs. W.H. Freeman \& Company.

DUQUE-CARO, H., 1990a: Estratigrafía, paleoceanografía y paleobiogeografía de la cuenca del Atrato y la evolución del Istmo de Panamá. - Inst. Nac. Invest. Geol.-Mineras. Bol. Geol. 31(1): 3-46.

DUQUE-CARO, H., 1990b: El Bloque Chocó en el
Noroccidente Suramericano: Implicaciones estructurales, ectonoestratigráficas y paleogeográficas. - Inst. Nac. Invest. Geol.-Mineras. Bol. Geol. 31(1): 47-71.

ESTES, R. \& BÁEZ, A., 1985: Herpetofaunas of North and South America during the Late Cretaceous and Cenozoic: Evidence for interchange? - In: STHELI, F.G. \& WEBB, S.D. (eds.): The great American biotic interchange. Plenun Press, Topics in Geobiology, 4: 139-197.

HULBERT, R.C. Jr., 2001: The fossil vertebrates of Florida -350 pp. Univ. Press of Florida, Gainesville.

LAURITO, C.A. \& VALERIO, A.L.: First record of Rhynchotherium blicki (Frick, 1933) from the late Cenozoic of Costa Rica. - Rev. Geol. Amér. Central (in press).

MEYLAN, P.A., 1987: The phylogenetic relationships of soft-shelled turtles (family Trionychidae). - Bull. Amer. Mus. Nat. Hist. 186: 1-110.

MARSHALL, L.G., 1985: Geochronology and land mammal biochronology of the transamerican faunal interchange. - In: Stheli, F.G. \& Webb, S.D. (eds.): The great American biotic interchange. - Plenun Press, Topics in Geobiology, 4: 49-85.

SÁNCHEZ-VILLAGRA, M.R., ASHER, R.J., RINCÓN, A.D., CARLINI, A., MEYLAN, P. \& PURDY, W., 2004: New faunal reports for the cerro La Cruz locality (Lower Miocene), North-Western Venezuela. - In: SÁNCHEZ-VILLAGRA, M.R. \& CLACK, J.A. (eds.): Fossil of the Miocene Castillo Formation, Venezuela: Contributions on neotropical paleontology. - Spec. Papers in Paleont. 71: 105-112.

SHEIL, C.A., 2003: Osteology and skeletal development of Apalone spinifera (Reptilia: Testudines: Trionychidae). - J. Morphology, 256: 42-78.

FLYNN, J. J. \& SWISHER, C. C., 1995, Cenozoic South American land mammal ages: Correlation to global geochronologies: - SEPM Spec. Publ. 54: 317-333

WEBB, R.C., 1990: Trionyx. - Catalogue Amer. amphibians reptiles, 487: 1-7.

WHITEMORE, F.C. \& STEWART, R.H.; 1965: Miocene mammals and Central American seaways. - Science, 148: $180-185$

WOOD, R.C. \& PATTERSON, B., 1973: A fossil tryonychid turtle from South America. - Brevoria, 405: 1-10. 
